\title{
PENGARUH RETURN ON ASSET (ROA) DAN RETURN ON EQUITY (ROE) TERHADAP HARGA SAHAM PADA PERUSAHAAN MANUFAKTUR YANG TERDAFTAR DI INDONESIA PERIODE 2017-2019
}

\author{
Mahdi Hendrich \\ Universitas Sjakhyakirti Palembang \\ mahdihendrich@unisti.ac.id, \\ mahdihendrich03@gmail.com
}

\begin{abstract}
This study attempts to examine how much influence these two variables, namely ROA and ROE, on stock prices, especially in manufacturing companies of the type of "Consumer Goods" listed on the Indonesia Stock Exchange, the Malaysia Stock Exchange and the Thailand Stock Exchange. The sampling technique used was purposive sampling based on certain criteria or considerations. The sample taken is the financial statements of 9 companies that have been determined in accordance with the provisions of sampling with the period 2017-2019. The result shows that, simultaneously, Return On Asset (ROA) and Return On Equity (ROE) have a positive effect on stock prices in manufacturing companies in Indonesia. The coefficient of determination $(R 2)$ of 0.238 indicates that each share price is influenced by the ROA, ROE and State variables of $23.8 \%$ while the remaining $76.2 \%$ is influenced by other variables not examined.
\end{abstract}

Keyword: Share Price, ROA, ROE, Manufacture firms

\section{PENDAHULUAN}

Pada tahun 2015 resmi dibuka perdagangan bebas ekonomi di ASEAN yang biasa disebut dengan ASEAN Economic Community (AEC). Perdagangan bebas antar negara menuntut Indonesia untuk meningkatkan kinerja ekonomi dari segala sektor termasuk sektor manufaktur yang ada di Indonesia dan dituntut siap untuk bersaing ketat dengan perusahaan domestik maupun internasional. Untuk mengatasi hal tersebut diperlukan tambahan dana yang besar dalam bentuk investasi di pasar modal.

Pasar modal merupakan pertemuan antara pihak yang memiliki kelebihan dana dengan pihak yang membutuhkan dana dengan cara memperjualbelikan sekuritas. Pasar modal juga bisa diartikan sebagai pasar untuk memperjualbelikan 
sekuritas yang umumnya memiliki umur lebih dari satu tahun, seperti saham dan obligasi (Tandelilin, 2008:13).

Harga saham mencerminkan nilai dari suatu perusahaan. Jika perusahaan mencapai prestasi yang baik, maka saham perusahaan tersebut akan banyak diminati oleh para investor. Prestasi baik yang dicapai perusahan dapat dilihat di dalam laporan keuangan yang dipublikasikan oleh perusahaan (emiten).

Rasio yang umum digunakan sebagai alat ukur kinerja keuangan perusahaan adalah Return on Assets (ROA). Return on Asset mengukur kemampuan perusahaan dalam menghasilkan laba bersih berdasarkan tingkat aset tertentu (Hanafi, 2008:42). Semakin tinggi Return on Asset suatu perusahaan, semakin besar pula tingkat keuntungan yang dicapai oleh perusahaan. Return on Asset perlu dipertimbangkan oleh investor dalam berinvestasi saham, karena Return on Asset berperan sebagai indikator efisiensi perusahaan dalam menggunakan aset untuk memperoleh laba.

Selain dengan menggunakan ROA untuk mengukur kinerja keuangan juga dapat menggunakan Return On Equity (ROE). Menurut Lestari dan Sugiharto (2007:196) ROE adalah rasio yang digunakan untuk mengukur keuntungan bersih yang diperoleh dari pengelolaan modal yang diinvestasikan oleh pemilik perusahaan. ROE diukur dengan perbandingan antara laba bersih dengan total modal. Angka ROE yang semakin tinggi memberikan indikasi bagi para pemegang saham bahwa tingkat pengembalian investasi makin tinggi.

Salah satu alasan utama perusahaan beroperasi adalah menghasilkan laba yang bermanfaat bagi para pemegang saham. Ukuran dari keberhasilan pencapaian alasan ini adalah angka ROA maupun ROE yang berhasil dicapai. Semakin besar ROA dan ROE mencerminkan kemampuan perusahaan dalam menghasilkan keuntungan yang tinggi bagi pemegang saham. Hal ini berdampak terhadap peningkatan nilai perusahaan.

Kasmir (2014:196) menjelaskan pengertian rasio profitabilitas adalah : Rasio profitabilitas merupakan rasio untuk menilai kemampuan perusahaan dalam mencari keuntungan, rasio ini juga memberikan ukuran tingkat efektifitas manajemen suatu perusahaan. Hal ini ditunjukkan oleh laba yang dihasilkan dari 
penjualan dan pendapatan investasi. Pada dasarnya penggunaan rasio ini yakni menunjukkan tingkat efesiens Perusahaan.

Tabel 1

Standar Pengukuran Rasio Profitabilitas

\begin{tabular}{|l|l|l|l|}
\hline No & $\begin{array}{c}\text { Rasio } \\
\text { Profitabilitas }\end{array}$ & \multicolumn{1}{|c|}{ Standar } & \multicolumn{1}{|c|}{ Kriteria } \\
\hline \multirow{4}{*}{1} & \multirow{4}{*}{ ROA } & $>1,5 \%$ & Sangat Baik \\
\cline { 3 - 4 } & & $1,25 \% \mathrm{~s} / \mathrm{d}<1,5 \%$ & Baik \\
\cline { 3 - 4 } & $0,5 \% \mathrm{~s} / \mathrm{d}<1,25 \%$ & Cukup Baik \\
\cline { 3 - 4 } & $0 \% \mathrm{~s} / \mathrm{d}<0,5 \%$ & Kurang Baik \\
\cline { 3 - 4 } 2 & $<0 \%$ & Tidak Baik \\
\hline \multirow{4}{*}{2} & $>15 \%$ & Sangat Baik \\
\cline { 3 - 4 } & \multirow{4}{*}{ ROE } & $1.25 \% \mathrm{~s} / \mathrm{d}<15 \%$ & Baik \\
\cline { 3 - 4 } & & $5 \% \mathrm{~s} / \mathrm{d}<12,5 \%$ & Cukup Baik \\
\cline { 3 - 4 } & $0 \% \mathrm{~s} / \mathrm{d}<5 \%$ & Kurang Baik \\
\cline { 3 - 4 } & $<0 \%$ & Tidak Baik \\
\hline
\end{tabular}

Sumber : Diolah Penulis 2020

Berikut ini adalah rasio profitabilitas beberapa perusahaan yang tercatat dalam Bursa Efek.

Tabel 2

Rekapitulasi Data Return On Asset Tahun 2017 - 2019

\begin{tabular}{|c|l|c|c|c|}
\hline \multirow{2}{*}{ No } & \multirow{2}{*}{ Kode } & \multicolumn{3}{c|}{ Return On Asset } \\
\cline { 3 - 5 } & & $\mathbf{2 0 1 7}$ & $\mathbf{2 0 1 8}$ & $\mathbf{2 0 1 9}$ \\
\hline 1 & AISA & 5.13 & 4.12 & 7.77 \\
\hline 2 & CEKA & 3 & 7 & 18 \\
\hline 3 & ICBP & 11.1 & 11,3 & 13.1 \\
\hline 4 & MAYOR & 4 & 11 & 11 \\
\hline 5 & ROTI & 8.8 & 10 & 9.6 \\
\hline 6 & SKBM & 13.11 & 5.28 & 2.11 \\
\hline 7 & SKLT & 5.1 & 5.3 & 3.5 \\
\hline 8 & STTP & 7.27 & 9.67 & 9.7 \\
\hline 9 & ULTJ & 9.7 & 14.78 & 16.74 \\
\hline
\end{tabular}

Sumber : www.idx.co.id

Berdasarkan tabel tersebut dapat diketahui bahwa pada tahun 2017 ROA tertinggi dimiliki SKBM dengan persentase $13.11 \%$ dan yang terendah dimiliki CEKA dengan persentase 3\%. Di tahun 2018, ROA tertinggi dimiliki ULTJ dengan persentase $14.6 \%$ dan yang terendah dimiliki AISA dengan persentase $4.12 \%$. Di tahun 2019, ROA tertinggi dimiliki CEKA dengan persentase $18 \%$ dan yang terendah dimiliki SKBM dengan persentase $2.11 \%$. 
Tabel 3

Rekapitulasi Data Return On Equity Tahun 2017 - 2019

\begin{tabular}{|c|l|c|c|c|}
\hline \multirow{2}{*}{ No } & \multirow{2}{*}{ Kode } & \multicolumn{3}{c|}{ Return On Asset } \\
\cline { 3 - 5 } & & $\mathbf{2 0 1 7}$ & $\mathbf{2 0 1 8}$ & $\mathbf{2 0 1 9}$ \\
\hline 1 & AISA & 10.54 & 9.42 & 16.87 \\
\hline 2 & CEKA & 8 & 17 & 28 \\
\hline 3 & ICBP & 18.8 & 18.9 & 20.8 \\
\hline 4 & MAYOR & 10 & 24 & 22 \\
\hline 5 & ROTI & 19.78 & 22.76 & 19.39 \\
\hline 6 & SKBM & 27.91 & 11.73 & 5.74 \\
\hline 7 & SKLT & 12.3 & 13.2 & 6.9 \\
\hline 8 & STTP & 15.01 & 16.41 & 18.7 \\
\hline 9 & ULTJ & 12.45 & 18.7 & 20.34 \\
\hline
\end{tabular}

Sumber : $\underline{w w w . i d x . c o . i d}$

Berdasarkan tabel tersebut dapat diketahui bahwa pada tahun 2017 ROE tertinggi dimiliki SKBM dengan persentase $27.91 \%$ dan yang terendah dimiliki CEKA dengan persentase 8\%. Di tahun 2018, ROE tertinggi dimiliki ROTI dengan persentase $22.76 \%$ dan yang terendah dimiliki AISA dengan persentase $9.42 \%$. Di tahun 2019, ROE tertinggi dimiliki CEKA dengan persentase $28 \%$ dan yang terendah dimiliki SKBM dengan persentase 5,74\%.

Penelitian ini mencoba untuk meneliti seberapa besar pengaruh kedua variabel tersebut yaitu ROA dan ROE terhadap harga saham khususnya pada perusahaan manufaktur jenis "Consumer Goods" yang terdaftar di Bursa Efek Indonesia, Bursa Efek Malaysia dan Bursa Efek Thailand. Mengingat belum diketahuinya seberapa besar hasil dari pengaruh ROA dan ROE terhadap harga saham di tingkat ASEAN dan juga belum ada penelitian relevan sebelumnya yang meneliti hingga tingkat ASEAN. Saat ini juga masih banyak investor yang belum mengetahui informasi mengenai investasi saham di tingkat ASEAN sehingga keputusan untuk berinvestasi masih terasa sulit.

\section{LANDASAN TEORI}

\section{Harga Saham}

a. Pengertian Harga Saham 
Menurut Jogiyanto (2008:143) harga saham adalah harga yang terjadi di pasar bursa pada saat tertentu yang ditentukan oleh pelaku pasar dan ditentukan oleh permintaan dan penawaran saham yang bersangkutan di pasar modal. Menurut Suad Husnan dan Enny Pudjiastuti (2004:151) harga saham merupakan nilai sekarang (present value) dari penghasilan-penghasilan yang akan diterima oleh pemodal dimasa yang akan datang. Dapat disimpulkan harga saham adalah harga selembar saham yang terjadi pada saat tertentu yang ditentukan oleh permintaan dan penawaran di pasar modal.

b. Penilaian Harga Saham

Penilaian saham adalah suatu mekanisme untuk merubah serangkaian variabel ekonomi/variabel perusahaan yang diramalkan menjadi perkiraan tentang harga saham misalnya laba perusahaan dan deviden yang dibagikan, maksudnya suatu metode untuk mencari nilai-nilai saham yang menjadi ukuran dalam investasi surat berharga. Tujuan penilaian saham adalah untuk memberikan gambaran pada manajemen atas estimasi nilai saham suatu perusahaan yang akan digunakan sebagai rujukan manajemen sebagai pertimbangan kebijakan atas saham perusahaan bersangkutan.

\section{Analisis Harga Saham}

Analisis harga saham umumnya dapat dilakukan oleh para investor dengan mengamati dua pendekatan dasar yaitu:

\section{Analisis Teknikal}

Analisis teknikal merupakan upaya untuk memperkirakan harga saham dengan mengamati perubahan harga saham tersebut di waktu yang lalu (Husnan, 2005:349). Analisis teknikal adalah pendekatan investasi dengan cara mempelajari data historis dari harga saham serta menghubungkannya dengan trading volume yang terjadi dan kondisi ekonomi pada saat itu. Analisis ini hanya mempertimbangkan pergerakan harga saham saja tanpa memperhatikan kinerja perusahaan yang mengeluarkan saham.

2. Analisis Fundamental

Analisis fundamental merupakan faktor yang erat kaitannya dengan kondisi perusahaan yaitu kondisi manajemen organisasi sumber daya manusia dan 
kondisi keuangan perusahaan yang tercermin dalam kinerja keuangan perusahaan. Analisis fundamental mencoba memperkirakan harga saham di masa yang akan datang dengan mengestimasi nilai faktor-faktor fundamental yang mempengaruhi harga saham di masa yang akan datang dan menetapkan hubungan variabelvariabel tersebut sehingga diperoleh taksiran harga saham (Husnan, 2005:315).

\section{Return On Asset (ROA)}

Return On Asset (ROA) menurut Hanafi dan Halim (2004:83) adalah rasio yang mengukur kemampuan perusahaan menghasilkan laba dengan menggunakan total asset (kekayaan) yang dipunyai perusahaan setelah disesuaikan dengan biayabiaya untuk mendanai asset tersebut. ROA merupakan indikator kemampuan sebuah unit usaha untuk memperoleh laba atas sejumlah aset yang dimiliki oleh unit usaha tersebut. Semakin tinggi rasio ini, semakin baik suatu perusahaan. Rumus yang digunakan untuk mengukur ROA adalah sebagai berikut:

$$
R O A=\frac{\text { Laba Bersih }}{\text { Total Aktiva }} \times 100 \%
$$

(Sumber : Hanafi dan Halim ,2004)

\section{Return On Equity (ROE)}

Menurut Harahap (2007:156) ROE digunakan untuk mengukur besarnya pengembalian terhadap investasi para pemegang saham. Angka tersebut menunjukkan seberapa baik manajemen memanfaatkan investasi para pemegang saham. ROE diukur dalam satuan persen. Tingkat ROE memiliki hubungan yang positif dengan harga saham, sehingga semakin besar ROE semakin besar pula harga pasar, karena besarnya ROE memberikan indikasi bahwa pengembalian yang akan diterima investor akan tinggi sehingga investor akan tertarik untuk membeli saham tersebut, dan hal itu menyebabkan harga pasar saham cendrung naik.

$$
\begin{aligned}
& R O E=\frac{\text { Laba Bersih }}{\text { Total Modal Sendiri }} \times 100 \% \\
& \text { Sumber : Lestari dan Sugiharto,2007 }
\end{aligned}
$$




\section{Penelitian yang Relevan}

Berikut ini beberapa penelitian-penelitian yang relevan dengan penelitian ini. Penelitian-penelitian tersebut digunakan sebagai acuan (refersnsi) dan pembanding terhadap hasil-hasil yang akan diperoleh pada penelitian ini. Penelitian-penelitian tersebut adalah sebagai berikut.

1. Penelitian oleh Helmy Fahrizal (2013) dengan judul "Pengaruh Retun On Assets, Return On Equity, and Investment Opportunity Set Terhadap Nilai Perusahaan" (Studi Empiris pada Perusahaan Manufaktur Jenis Consumer Goods yang Terdaftar di Bursa Efek Indonesia).

2. Penelitian oleh Rescyana Putri Hutami (2012) dengan judul "Pengaruh Dividen Per Share, Return On Equity dan Net Profit Margin Terhadap Harga Saham Perusahaan Industri Manufaktur yang Tercatat di Bursa Efek Indonesia Periode 2006-2010".

3. Penelitian yang dilakukan oleh Ina Rinati (2008) dengan judul "Pengaruh Net Profit Margin (NPM), Retrun On Asset (ROA) dan Return On Equity (ROE) terhadap Harga Saham pada Perusahaan yang Tercantum dalam Indeks LQ45”

\section{Kerangka Berpikir}

Kerangka berpikir dalam penelitian ini digambarkan pada bagan sebagai berikut

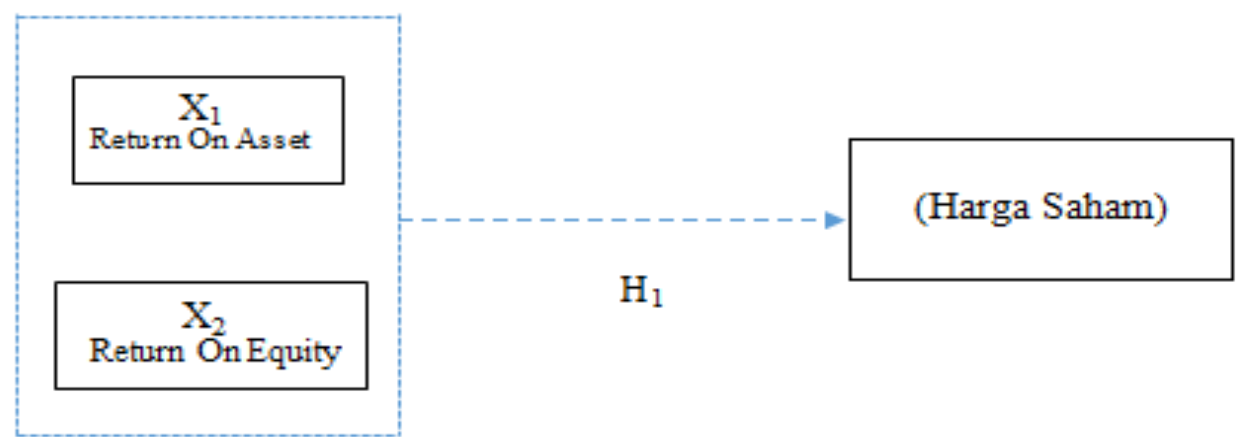

Sumber: Sugiono: 2016

\section{Gambar 1. Diagram hubungan antar variabel bebas (ROA \& ROE) Hipotesis Penelitian dan variabel terikat (Harga Saham).}

Hipotesis dalam penelitian ini dapat dirumuskan sebagai berikut :

$\mathrm{H}_{0}$ : ROA dan ROE tidak berpengaruh positif terhadap Harga Saham pada perusahaan manufaktur di Negara ASEAN. 
$\mathrm{H}_{1}$ : ROA dan ROE berpengaruh positif terhadap Harga Saham pada perusahaan manufaktur di Negara ASEAN.

\section{METODE PENELITIAN}

\section{Ruang Lingkup Penelitian}

Penelitian dilakukan pada perusahaan manufaktur jenis consumer goods yang terdaftar di bursa efek ketiga negara yaitu Bursa Efek Indonesia, Bursa Malaysia dan The Stock Exchange of Thailand berdasarkan data yang didapat melalui beberapa situs web yang relevan dengan masalahnya yaitu www.idx.co.id, www.sahamok.com, www.bursamalaysia.com, www.financials.morningstar.com, dan www.set.or.th.

\section{Populasi dan Sampel}

Populasi yang digunakan dalam penelitian ini adalah perusahaan industri manufaktur jenis consumer goods yang go public dan aktif di Bursa Efek Indonesia, Bursa Malaysia dan The Stock Exchange of Thailand tahun 2017 - 2019. Jumlah populasi adalah sebanyak 90 perusahaan.

Teknik penarikan sampel yang digunakan adalah purposive sampling, yaitu salah satu teknik pengambilan sampel non probability yang dilakukan berdasarkan kriteria atau pertimbangan tertentu (Indriantoro dan Bambang, 2002:120). Penulis menentukan kriteria sampel sebagai berikut :

a. Perusahaan manufaktur menerbitkan Laporan Keuangan Konsolidasian (audited) untuk periode yang berakhir pada 31 Desember selama periode penelitian.

b. Perusahaan tidak berubah sektor industrinya selama periode penelitian.

c. Perusahaan tidak delisting dari bursa efek selama periode penelitian.

d. Perusahaan sampel memiliki semua data yang diperlukan secara lengkap.

e. Perusahaan memiliki data harga penutupan saham akhir tahun dimana saham tersebut aktif diperdagangkan selama periode penelitian.

\section{Teknik Pengumpulan Data}

Data yang digunakan dalam penelitian ini adalah data sekunder yaitu data yang diperoleh peneliti secara tidak langsung melalui media perantara (diperoleh dan dicatat oleh pihak lain). Oleh karena itu, teknik pengumpulan data yang digunakan ialah dokumentasi yang dilakukan dengan cara penyalinan dan 
pengarsipan data-data dari sumber terpecaya. Data sekunder dalam penelitian ini didapatkan dari www.idx.co.id, www.sahamok.com, www.bursamalaysia.com, www. financials.morningstar.com dan www.set.or.th.

Selain itu peneliti juga melakukan penelitian kepustakaan dengan memperoleh data yang berkaitan dengan pembahasan yang sedang diteliti melalui berbagai literatur yang relevan dengan penelitian ini.

\section{Teknik Analisis Data}

\section{Uji Asumsi Klasik}

Penjelasan mengenai hubungan tersebut dalam penenlitian ini menggunakan pendekatan analisis regresi linier berganda. Sebelum dilakukan analisis regresi linier berganda dan untuk menjamin kenormalan distribusi data agar hasil analisis penelitian tidak bias, maka terlebih dahulu dilakukan uji asumsi klasik. Uji asumsi klasik meliputi empat macam pengujian yakni : uji multikolinieritas, uji autokorelasi, uji normalitas dan uji heteroskeditastisitas. Berikut ini adalah penjelasan dari keempat uji tersebut :

a. Uji Multikoliniearitas

Uji multikolinieritas bertujuan untuk menguji apakah pada model regresi ditemukan adanya korelasi antar variabel bebas (independent). Untuk mendeteksi ada atau tidaknya multikolinieritas di dalam model regresi dapat dilihat dari nilai tolerance dan VIF (Variance Inflation Factor). Kedua ukuran ini menunjukkan setiap variabel independen manakah yang dijelaskan oleh variabel independen lainnya. Jika nilai tolerance $\leq 0.10$ atau sama dengan $\mathrm{VIF} \geq 10$, nilai tersebut menunjukkan adanya multikolinieritas (Ghozali, 2006:95-96).

\section{b. Uji Autokorelasi}

Uji autokorelasi bertujuan menguji apakah dalam model regresi ada korelasi antara kesalahan pengganggu pada periode $t$ dengan kesalahan pengganggu pada periode t-1 (sebelumnya) (Ghozali, 2006:99). Pengambilan keputusan ada tidaknya autokorelasi melalui kriteria DW tabel dengan tingkat signifikansi 5\%

c. Uji Normalitas 
Uji normalitas bertujuan untuk menguji apakah data berdistribusi normal atau tidak. Jika uji tidak terpenuhi, maka uji statistik menjadi tidak valid untuk jumlah sampel kecil. Uji normalitas dapat diuji dengan menggunakan uji Kolmogorof Smirnov (KS).

d. Uji Heteroskedastisitas

Uji heteroskedastisitas bertujuan menguji apakah dalam model regresi terjadi ketidaksamaan varians dari residual satu pengamatan ke pengamatan yang lain. Jika varians dari residual satu pengamatan ke pengamatan yang lain tetap, maka disebut homoskedastisitas dan jika berbeda disebut heteroskedastisitas (Ghozali, 2006:125). Deteksi ada tidaknya heteroskedastisitas dilakukan dengan melihat ada tidaknya pola tertentu pada grafik scatterplot.

\section{Regresi dan Pengujian Hipotesis}

Persamaan regresi yang diinterprestasikan dalam penelitian ini adalah sebagai berikut:

$\mathrm{Y}=\alpha+\beta_{1} \mathrm{ROA}+\beta_{2} \mathrm{ROE}+\beta_{3} \mathrm{NEGARA}$

Keterangan:

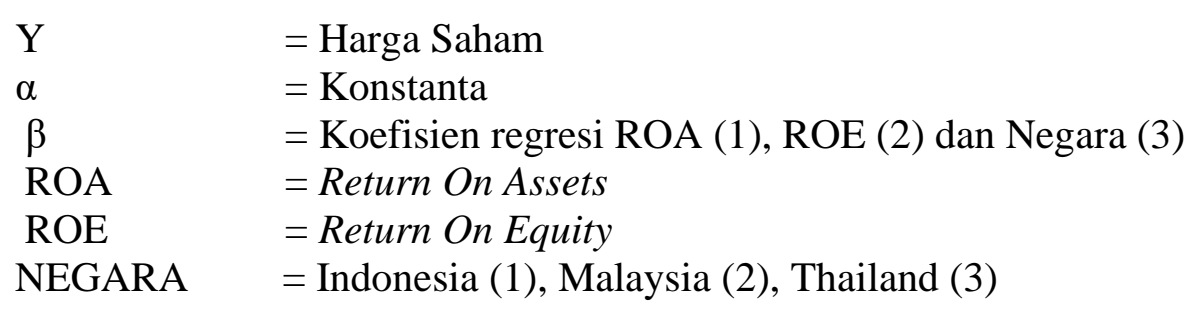

\section{Koefisien Determinaso (Adjusted $\mathbf{R}^{2}$ )}

Koefisien determinasi (Adjusted $R^{2}$ ) pada intinya mengukur seberapa jauh kemampuan model dalam menerangkan variasi variabel dependen. Nilai koefisien determinasi adalah antara nol dan 1 atau $(0<\mathrm{x}<1)$. Nilai adjusted $\mathrm{R}^{2}$ yang kecil berarti kemampuan variabel-variabel independen dalam menjelaskan variabelvariabel dependen amat terbatas. Nilai yang mendekati 1 berarti variabelvariabel independen memberikan hampir semua informasi yang dibutuhkan untuk memprediksi variabel dependen (Ghozali, 2006:87). 


\section{Uji F}

Uji statistik F menunjukkan apakah semua variabel independen atau bebas yang dimasukkan dalam model mempunyai pengaruh secara bersama-sama terhadap variabel dependen atau terikat (Ghozali, 2006:62). Pengambilan keputusan dilakukan dengan cara membandingkan nilai probabilitas (dalam output SPSS tertulis SIG) dengan besarnya alpha $(\alpha)$ yaitu 0,05 .

\section{HASIL DAN PEMBAHASAN}

\section{Hasil Penelitian}

Berikut ini adalah rincian perolehan sampel perusahaan manufaktur jenis consumer goods dengan kriteria-kriteria yang ditentukan sesuai dengan kebutuhan analisis.

Tabel 3.

Rincian Perolehan Sampel Penelitian

\begin{tabular}{|l|c|}
\hline \multicolumn{1}{|c|}{ Kriteria } & Jumlah \\
\hline $\begin{array}{l}\text { Perusahaan manufaktur menerbitkan Laporan Keuangan } \\
\text { Konsolidasian (audited) untuk periode yang berakhir pada 31 } \\
\text { Desember selama periode penelitian. }\end{array}$ & 90 \\
\hline $\begin{array}{l}\text { Perusahaan tidak berubah sektor industrinya selama periode } \\
\text { penelitian. }\end{array}$ & - \\
\hline Perusahaan tidak delisting dari bursa efek selama periode penelitian. & - \\
\hline $\begin{array}{l}\text { Perusahaan sampel memiliki semua data yang diperlukan secara } \\
\text { lengkap. }\end{array}$ & $(24)$ \\
\hline $\begin{array}{l}\text { Perusahaan memiliki data harga penutupan saham akhir tahun dimana } \\
\text { saham tersebut aktif diperdagangkan selama periode penelitian. }\end{array}$ & $(21)$ \\
\hline Jumlah perusahaan manufaktur yang menjadi sampel. & 45 \\
\hline
\end{tabular}

Sumber: Data sekunder yang diolah

Berdasarkan hasil penelitian, diperoleh sampel perusahaan yang memenuhi kriteria yang telah ditentukan sebanyak 45 perusahaan, dengan tahun pengamatan 3 tahun berturut-turut. Maka 3 tahun observasi x 9 sampel $=27$ observasi.

\section{Nilai ROA}

Tabel 4

Rekapitulasi Data Return On Asset Tahun 2017 - 2019

\begin{tabular}{|c|l|c|c|c|}
\hline \multirow{2}{*}{ No. Kode } & \multirow{3}{*}{ Return On Aset } \\
\cline { 3 - 5 } & & $\mathbf{2 0 1 7}$ & $\mathbf{2 0 1 8}$ & $\mathbf{2 0 1 9}$ \\
\hline 1 & AISA & 5.13 & 4.12 & 7.77 \\
\hline 2 & CEKA & 3 & 7 & 18 \\
\hline 3 & ICBP & 11.1 & 11,3 & 13.1 \\
\hline
\end{tabular}




\begin{tabular}{|c|l|c|c|c|}
\hline \multirow{2}{*}{ No. } & \multirow{2}{*}{ Kode } & \multicolumn{3}{|c|}{ Return On Aset } \\
\cline { 3 - 5 } & & $\mathbf{2 0 1 7}$ & $\mathbf{2 0 1 8}$ & $\mathbf{2 0 1 9}$ \\
\hline 4 & MAYOR & 4 & 11 & 11 \\
\hline 5 & ROTI & 8.8 & 10 & 9.6 \\
\hline 6 & SKBM & 13.11 & 5.28 & 2.11 \\
\hline 7 & SKLT & 5.1 & 5.3 & 3.5 \\
\hline 8 & STTP & 7.27 & 9.67 & 9.7 \\
\hline 9 & ULTJ & 9.7 & 14.78 & 16.74 \\
\hline
\end{tabular}

Sumber : $\underline{w w w . i d x . c o . i d}$

Berdasarkan tabel tersebut dapat diketahui bahwa pada tahun 2017 ROA tertinggi dimiliki SKBM dengan persentase $13.11 \%$ dan yang terendah dimiliki CEKA dengan persentase 3\%. Di tahun 2018, ROA tertinggi dimiliki ULTJ dengan persentase $14.6 \%$ dan yang terendah dimiliki AISA dengan persentase 4.12\%. Di tahun 2019, ROA tertinggi dimiliki CEKA dengan persentase $18 \%$ dan yang terendah dimiliki SKBM dengan persentase $2.11 \%$.

\section{Nilai ROE}

Tabel 5

Rekapitulasi Data Return On Equity Tahun 2017 - 2019

\begin{tabular}{|c|l|c|c|c|}
\hline \multirow{2}{*}{ No. Kode } & \multirow{2}{*}{ Keturn On Aset } \\
\cline { 3 - 5 } & & $\mathbf{2 0 1 7}$ & $\mathbf{2 0 1 8}$ & $\mathbf{2 0 1 9}$ \\
\hline 1 & AISA & 10.54 & 9.42 & 16.87 \\
\hline 2 & CEKA & 8 & 17 & 28 \\
\hline 3 & ICBP & 18.8 & 18.9 & 20.8 \\
\hline 4 & MAYOR & 10 & 24 & 22 \\
\hline 5 & ROTI & 19.78 & 22.76 & 19.39 \\
\hline 6 & SKBM & 27.91 & 11.73 & 5.74 \\
\hline 7 & SKLT & 12.3 & 13.2 & 6.9 \\
\hline 8 & STTP & 15.01 & 16.41 & 18.7 \\
\hline 9 & ULTJ & 12.45 & 18.7 & 20.34 \\
\hline
\end{tabular}

Sumber : $\underline{w w w . i d x . c o . i d}$

Berdasarkan tabel tersebut dapat diketahui bahwa pada tahun 2017 ROE tertinggi dimiliki SKBM dengan persentase $27.91 \%$ dan yang terendah dimiliki CEKA dengan persentase 8\%. Di tahun 2018, ROE tertinggi dimiliki ROTI dengan persentase $22.76 \%$ dan yang terendah dimiliki AISA dengan persentase $9.42 \%$. Di tahun 2019, ROE tertinggi dimiliki CEKA dengan persentase $28 \%$ dan yang terendah dimiliki SKBM dengan persentase 5,74\%

\section{Uji Asumsi Klasik}

A. Uji Multikolinieritas 
Hasil dari uji multikolinieritas dengan regresi sebagai berikut :

Tabel 6. Hasil Uji Multikolinieritas

\begin{tabular}{|c|c|c|c|c|c|c|c|}
\hline \multirow[b]{2}{*}{ Model } & \multicolumn{2}{|c|}{$\begin{array}{l}\text { Unstandardized } \\
\text { Coefficients }\end{array}$} & \multirow{2}{*}{$\begin{array}{c}\text { Standardized } \\
\text { Coefficients } \\
\text { Beta }\end{array}$} & \multirow[b]{2}{*}{$t$} & \multirow[b]{2}{*}{ Sig. } & \multirow{2}{*}{$\begin{array}{c}\text { Collinearit } \\
\text { Statistics } \\
\text { Tolera nce }\end{array}$} & \multirow[b]{2}{*}{$V I F$} \\
\hline & $B$ & $\begin{array}{l}\text { Std. } \\
\text { Error }\end{array}$ & & & & & \\
\hline 1 (Constant) & $-15369,220$ & 9334,044 & & $-1,647$ & 0,102 & & \\
\hline ROA & $-318,103$ & 878,016 & $-0,066$ & $\mid-0,362$ & 0,718 & $\begin{array}{l}0,109 \\
0,171 \\
0.972\end{array}$ & $\begin{array}{l}5,842 \\
1029\end{array}$ \\
\hline ROE & 889,488 & 312,723 & 0,518 & 2,844 & 0,005 & & \\
\hline Negara & 11765,150 & $3417,582 \mid$ & 0,263 & 3,443 & 0,001 & & \\
\hline
\end{tabular}

Pada tabel 5 di atas hasil perhitungan menunjukkan semua variabel memiliki nilai tolerance lebih dari 0,1 dan memiliki nilai VIF kurang dari 10. Maka dapat disimpulkan bahwa variabel bebas yang digunakan dalam penelitian ini tidak terjadi gejala multikolinieritas dalam model regresi.

B. Uji Autokorelasi

Pada penelitian ini menggunakan uji Durbin-Watson untuk mengetahui ada tidaknya autokorelasi. Adapun hasil uji autokorelasi dengan menggunakan DurbinWatson adalah sebagai berikut:

Tabel 7. Hasil Uji Autokorelasi

\begin{tabular}{|l|r|r|r|r|r|}
\hline Model & $R$ & $R$ Square & $\begin{array}{c}\text { Adjusted } R \\
\text { Square }\end{array}$ & $\begin{array}{r}\text { Std. Error of } \\
\text { the Estimate }\end{array}$ & Durbin-Watson \\
\hline 1 & $0,462^{\mathrm{a}}$ & 0,213 & 0,195 & 1,29867 & 2,211 \\
\hline
\end{tabular}

Sumber : Data sekunder yang telah diolah

Pada tabel 6 di atas menunjukkan bahwa nilai Durbin-Watson (DW) sebesar 2,211 yang akan dibandingkan dengan nilai pada tabel DW dengan menggunakan tingkat signifikansi 0,05. Nilai DW menurut tabel dengan jumlah sampel 9 (n) dan jumlah variabel independen $3(\mathrm{k})$ adalah $\mathrm{dl}=1.6738 \mathrm{dan} \mathrm{du}=1.7645$. Oleh karena itu nilai DW hitung lebih besar dari batas atas yaitu 1.7645 dan kurang dari 2.236 (4-1.7645), yaitu $1.7645<2.211<2.236$. Jadi dapat disimpulkan bahwa model regresi tersebut tidak mengalami autokorelasi (non autokorelasi). 


\section{Uji Normalitas}

Uji normalitas dalam penelitian ini menggunakan uji one-sample kolmogrov-smirnov yang dapat diketahui ketika data berdistribusi normal, maka nilai signifikasi harus $>0,05$. Hasil uji kolmogrov-smirnov penelitian ini sebagai berikut :

Tabel 8. Hasil Uji Normalitas

\begin{tabular}{|ll|r|}
\hline & & Unstandardized Residual \\
& & 45 \\
Normal Parameters ${ }^{a, b}$ & Mean & 140,1178 \\
& Std. Deviation & 97,22104 \\
Most Extreme Differences & Absolute & 0,168 \\
& Positive & 0,168 \\
& Negative & $-0,113$ \\
Kolmogorov-Smirnov $Z$ & & 1,117 \\
Asymp. Sig. (2-tailed) & & 0,165 \\
\hline
\end{tabular}

Berdasarkan hasil uji normalitas di atas dengan Kolmogrov-Smirnov diperoleh nilai Asymp.Sig (2 tailed) sebesar 0,165 dan Z hitung sebesar 1,117, sehingga dapat dikatakan data berdistribusi normal karena nilai Asymp.Sig > dari 0,05 dan Z hitung $<\mathrm{Z}$ tabel (sebesar 1,96).

D. Uji Heteroskedastisitas

Uji heteroskedastisitas digunakan untuk menguji terjadi ketidaksamaan variance atau tidak dari residual satu pengamatan ke pengamatan lainnya. Model regresi yang baik adalah yang tidak mengandung heteroskedastisitas. Jika variance dari residual satu pengamatan ke pengamatan lain tetap, maka disebut homoskedastisitas dan jika berbeda disebut heteroskedastisitas.

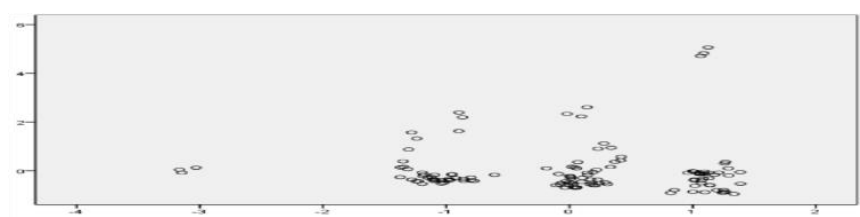

Gambar 2. Uji Heteroskedastisitas

Dari pengamatan grafik scatterplot di atas terlihat bahwa titik-titik menyebar secara acak serta tersebar baik di atas maupun di bawah angka nol pada sumbu Y, hal tersebut dapat disimpulkan bahwa tidak terjadi heteroskedastisitas atau non heteros pada model regresi, sehingga model regresi tersebut layak untuk 
memprediksi Harga Saham berdasarkan nilai Return On Asset (ROA) dan Return On Equity (ROE).

\section{Hasil Uji Hipotesis Penelitian}

Hipotesis dalam penelitian ini adalah ROA dan ROE berpengaruh positif terhadap Harga Saham pada perusahaan manufaktur di Negara ASEAN. Hasil uji hipotesis adalah sebagai berikut :

a. Persamaan Regresi

Tabel 9. Hasil Uji Regresi Berganda

\begin{tabular}{|c|c|c|c|c|c|c|}
\hline \multirow{2}{*}{\multicolumn{2}{|c|}{ Model }} & \multicolumn{2}{|c|}{ Unstandardized Coefficients } & \multirow{2}{*}{$\begin{array}{c}\begin{array}{c}\text { Standardized } \\
\text { Coefficients }\end{array} \\
\text { Beta }\end{array}$} & \multirow[b]{2}{*}{$t$} & \multirow[b]{2}{*}{ Sig. } \\
\hline & & $B$ & Std. Error & & & \\
\hline \multirow[t]{4}{*}{1} & \multirow{4}{*}{$\begin{array}{l}\text { (Constant) } \\
\text { ROA } \\
\text { ROE } \\
\text { Negara }\end{array}$} & $-15369,220$ & 9334,044 & & $-1,647$ & 0,102 \\
\hline & & $-318,103$ & 878,016 & $-0,066$ & $-0,362$ & 0,718 \\
\hline & & 889,488 & 312,723 & 0,518 & 2,844 & 0,005 \\
\hline & & 11765,150 & 3417,582 & 0,263 & 3,443 & 0,001 \\
\hline
\end{tabular}

Sumber: Hasil Olah Data

Berdasarkan tabel 8 di atas, maka persamaan regresi berganda dapat dinyatakan sebagai berikut:

$$
\mathrm{Y}=-15369,220-318,103 \mathrm{ROA}+889,488 \mathrm{ROE}+11765,150 \text { NEGARA }
$$

Berdasarkan persamaan tersebut dapat diketahui:

1) Nilai konstanta $-15369,220$ berarti bahwa jika seluruh variabel independen dianggap konstan maka nilai dependen (Harga Saham) adalah sebesar 15369,220 .

2) Nilai koefisien regresi ROA sebesar $-318,103$ berarti bahwa jika terjadi kenaikan 1 poin ROA maka nilai Harga Saham akan turun -318,103 poin.

3) Nilai koefisien regresi ROE sebesar 889,488 berarti bahwa jika terjadi kenaikan 1 poin ROE maka nilai Harga Saham akan naik 889,488 poin.

4) Nilai koefisien regresi NEGARA sebesar 11765,150 berarti bahwa jika terjadi kenaikan 1 poin NEGARA maka nilai Harga Saham akan naik 11765,150 poin. 


\section{b. Uji Adj R ${ }^{2}$}

Nilai koefisien determinasi $\left(\mathrm{R}^{2}\right)$ ini mencerminkan seberapa besar variasi dari variabel terikat $\mathrm{Y}$ dapat diterangkan oleh variabel bebas X.

Tabel 10. Hasil Uji Adj $\mathbf{R}^{2}$ (Koefisien Determinasi)

\begin{tabular}{|c|r|r|l|r|}
\hline \multirow{2}{*}{ Model } & $R$ & $R$ Square & $\begin{array}{l}\text { Adjusted } R \\
\text { Square }\end{array}$ & $\begin{array}{c}\text { Std. Error of the } \\
\text { Estimate }\end{array}$ \\
\hline 1 & $0,505^{\mathrm{a}}$ & 0,255 & & 0,238 \\
\end{tabular}

Sumber: Hasil Olah Data

Berdasarkan tabel 9 di atas, dapat dilihat bahwa nilai koefisien determinasi $\left(\mathrm{R}^{2}\right)$ sebesar 0,238. Nilai ini menunjukkan bahwa Harga Saham perusahaan manufaktur jenis "Consumer Goods" yang terdaftar di Bursa Efek Indonesia, dipengaruhi oleh 23,8\% variabel ROA, ROE dan Negara, sedangkan sisanya $76,2 \%$ dipengaruhi oleh variabel lain yang tidak dimasukkan dalam model ini.

c. Uji F

Berikut ini adalah hasil perhitungan uji $\mathrm{F}$

\section{Tabel 11. Hasil Uji F}

\begin{tabular}{|c|c|c|c|c|c|}
\hline Model & $\begin{array}{l}\text { Sum of } \\
\text { Squares }\end{array}$ & $d f$ & $\begin{array}{l}\text { Mean } \\
\text { Square }\end{array}$ & $F$ & Sig. \\
\hline $\begin{array}{ll}1 & \text { Regression } \\
& \text { Residual } \\
& \text { Total }\end{array}$ & $\begin{array}{c}4,587 \mathrm{E} 10 \\
1,338 \mathrm{E} 11 \\
1,797 \mathrm{E} 11\end{array}$ & $\begin{array}{r}3 \\
131 \\
134\end{array}$ & $\begin{array}{r}1,529 \mathrm{E} 10 \\
1,022 \mathrm{E} 9\end{array}$ & 14,966 & $0,000^{\mathrm{a}}$ \\
\hline
\end{tabular}

Sumber: Hasil Olah Data

Berdasakan tabel 10 di atas, nilai F hitung sebesar 14,966 dan lebih besar dari F tabel pada taraf signifikansi $5 \%$ yaitu 2,672. Nilai Sig sebesar 0,000 yang berarti lebih kecil dari 0,05 menunjukkan bahwa ROA dan ROE mempunyai pengaruh signifikan terhadap Harga Saham.

\section{Pembahasan}

Pengaruh Return On Asset (ROA) dan Return On Equity (ROE) terhadap Harga 
Saham Hasil penelitian ini menunjukkan bahwa Return On Asset dan Return On Equity secara bersama-sama berpengaruh signifikan terhadap Harga Saham. Hal ini dapat dilihat dari nilai $\mathrm{F}$ hitung sebesar 14,966 yang lebih besar dari F tabel pada taraf signifikansi 5\% yaitu 2,672 dan nilai signifikansi sebesar 0,000 yang berarti lebih kecil dari 0,05 menunjukkan bahwa ROA dan ROE mempunyai pengaruh yang signifikan terhadap Harga Saham. Nilai koefisien determinasi $\left(\mathrm{R}^{2}\right)$ sebesar 0,238 menunjukkan bahwa setiap Harga Saham dipengaruhi oleh variabel ROA, ROE dan Negara sebesar 23,8\% sedangkan sisanya 76,2\% dipengaruhi oleh variabel lain yang tidak diteliti.

Penelitian ini sejalan dengan penelitian yang dilakukan oleh Helmy Fahrizal (2013) dengan judul "Pengaruh Retun On Assets, Return On Equity, and Investment Opportunity Set Terhadap Nilai Perusahaan” (Studi Empiris pada Perusahaan Manufaktur Jenis Consumer Goods yang Terdaftar di Bursa Efek Indonesia) yang menyatakan bahwa variabel return on asset (ROA), return on equity (ROE), dan investment opportunity set (IOS) berpengaruh secara simultan dan signifikan terhadap nilai perusahaan dengan hasil uji statistik F yang nilai F hitung nya sebesar 575,392 dengan tingkat signifikansi sebesar 0,000. Tingkat signifikansi tersebut lebih kecil dari 0,05. Penelitian ini juga sejalan dengan penelitian yang dilakukan oleh Ina Rinati (2008) dengan judul "Pengaruh Net Profit Margin (NPM), Return On Asset (ROA) dan Return On Equity (ROE) terhadap Harga Saham pada Perusahaan yang Tercantum dalam Indeks LQ45" yang menyatakan bahwa NPM, ROA dan ROE berpengaruh positif terhadap Harga Saham dengan nilai F hitung lebih besar dari $\mathrm{F}$ tabel yaitu 13,248> 2,79 dan nilai sig 0,000 pada taraf signifikansi $5 \%$ yang secara simultan menunjukkan hasil yang sama (berpengaruh positif).

Hasil ini konsisten dengan teori dan pendapat yang dikemukakan oleh Mogdiliani dan Miller dalam Ulupui (2007:13-14) yang menyatakan bahwa nilai perusahaan ditentukan oleh earnings power dari aset perusahaan (ROA). Hasil yang positif menunjukkan bahwa semakin tinggi earnings power semakin efisien perputaran aset dan semakin tinggi profit margin yang diperoleh oleh perusahaan. Hal ini berdampak pada peningkatan nilai perusahaan yang dalam hal ini harga 
saham satu tahun ke depan. Menurut Chrisna (2011:34) kenaikan Return on Equity biasanya diikuti oleh kenaikan harga saham perusahaan tersebut. Semakin tinggi ROE berarti semakin baik kinerja perusahaan dalam mengelola modalnya untuk menghasilkan keuntungan bagi pemegang saham. Dapat dikatakan bahwa perusahaan tersebut dapat menggunakan modal dari pemegang saham secara efektif dan efisien untuk memperoleh laba. Dengan adanya peningkatan laba bersih maka nilai ROE akan meningkat pula sehingga para investor tertarik untuk membeli saham tersebut yang akhirnya harga saham perusahaan tersebut mengalami kenaikan.

\section{KESIMPULAN DAN SARAN}

Berdasarkan sampel penelitian yang diperoleh dari hasil analisis yang dilakukan maka dapat ditarik kesimpulan sebagai berikut:

Return On Asset (ROA) dan Return On Equity (ROE) secara simultan berpengaruh positif terhadap Harga Saham pada perusahaan manufaktur di Negara Indonesia. Hal ini ditunjukkan dengan nilai $\mathrm{F}$ hitung sebesar 14,966 yang lebih besar dari $\mathrm{F}$ tabel pada taraf signifikansi 5\% yaitu 2,672 dan nilai signifikansi sebesar 0,000 yang berarti lebih kecil dari 0,05 menunjukkan bahwa ROA dan ROE mempunyai pengaruh yang positif terhadap Harga Saham. Nilai koefisien determinasi $\left(\mathrm{R}^{2}\right)$ sebesar 0,238 menunjukkan bahwa setiap Harga Saham dipengaruhi oleh variabel ROA, ROE dan Negara sebesar 23,8\% sedangkan sisanya $76,2 \%$ dipengaruhi oleh variabel lain yang tidak diteliti.

\section{DAFTAR PUSTAKA}

Adiwibowo, Akhmad Sigit. 2018. Pengaruh Manajemen Laba, Ukuran Perusahaan dan Leverage Terhadap Return Saham dengan Kebijakan Dividen Sebagai Variabel Moderasi. Jurnal Ilmiah Akuntansi Universitas Pamulang. Vol. 6. No. 2. E-ISSN : 2599-1922.

Bionda, Azeria Ra \& Mahdar, Nera Marinda. 2017. Pengaruh Gross Profit Margin, Net Profit Margin, ROA dan ROE Terhadap Pertumbuhan Laba pada Perusahaan Manufaktur di BEI.

Bursa Malaysia dan The Stock Exchange of Thailand tahun 2017 - 2019. 
Fahmi. 2012. Analisis Kinerja Keuangan. ALFABETA: Bandung. Jumingan. 2017. Analisis Laporan Keuangan. Cetakan Keenam. Bumi Aksara: Jakarta.

Ghozali, Imam. 2013. Aplikasi Analisis Multivariate Dengan Program SPSS. Edisi Kelima. Badan Penerbit Universitas Diponegoro: Semarang.

Glenn Maguire (2015), Chief Economist South Asia, ASEAN and Pasific ANZ,

Hanafi, Mamduh dan Halim, Abdul. 2012. Analisis Laporan Keuangan. Edisi Ketiga Cetakan Pertama. Penerbit UPP Sekolah Tinggi Ilmu Manajemen YKPN: Yogyakarta.

Harahap, Sofyan Safri. 2018.Analisis Kritis Laporan Keuangan. Edisi Pertama. Cetakan 14. Raja Grafindo Persada: Jakarta. Hery. 2015. Pengantar Akuntansi Comprehensive. PT. Gramedia: Jakarta.

Helmy Fahrizal (2013), dengan judul "Pengaruh Retun On Assets, Return On Equity, and Investment Opportunity Set Terhadap Nilai Perusahaan" (Studi Empiris pada Perusahaan Manufaktur Jenis Consumer Goods yang Terdaftar di Bursa Efek Indonesia)

http://www.indopremier.com/ipotnews/newsDetail.php?jdl=Realisasi_Investasi_I ndutri_Manufaktur_Capai_Rp216_Triliun_di_Tahun_2019\&news_id=1153 54\&group_news=IPOTNEWS\&news_date=\&taging_subtype=MANUFAK TUR\&na me $=\&$ search $=y \_g e n e r a l \& q=$ industri\%20manufaktur\&haman $=1, \quad$ diakses pada $22 / 06 / 2020$

Huda, Nurul dan Nasution, Mustafa Edwin. 2008. Investasi Pada Pasar Modal Syariah. Jakarta : Kencana. Irham,

Ina Rinati (2008), "Pengaruh Net Profit Margin (NPM), Retrun On Asset (ROA) dan Return On Equity (ROE) terhadap Harga Saham pada Perusahaan yang Tercantum dalam Indeks LQ45

Jurnal Bisnis dan Komunikasi Kalbisocio Vol. 4. No. 1 ISSN : 2356-4385. Desiana, Lidia. 2018. Analisis Laporan Keuangan (Teori dan Pemahaman Materi). Cetakan I. CV. AMANAH: Palembang.

Kasmir. 2012. Analisis Laporan Keuangan. Cetakan Ketiga. PT. Raja Grafindo Persada: Jakarta.

Lukman. 2013. Manajemen Keuangan Perusahaan (Edisi Baru). Rajawali Pers. Jakarta.

Lulita, Wina. 2019. Pengaruh Return On Equity dan Net Profit Margin Terhadap Pertumbuhan Laba Pada Perusahaan Manufaktur yang Terdaftar di Bursa 
Efek Indonesia (BEI) Periode 2013-2017. Universitas Muhammadiyah Sumatera Utara. Medan.

Mahpudin, Endang. 2016. Faktor-faktor yang Mempengaruhi Nilai Perusahaan (Studi Empiris pada Perusahaan Manufaktur yang Terdaftar di Bursa Efek Indonesia). JRKA. Volume 2. Isue 2.

Munawir. 2012. Analisis Laporan Keuangan. Liberty: Yogyakarta.

Prawironegoro, Darsono \& Purwanti, Ari. 2013. Akuntansi Manajemen. Edisi Ketiga. Mitra Wacana Media: Jakarta.

Rescyana Putri Hutami (2012), "Pengaruh Dividen Per Share, Return On Equity dan Net Profit Margin Terhadap Harga Saham Perusahaan Industri Manufaktur yang Tercatat di Bursa Efek Indonesia Periode 2006-2010”.

Safitri, Anggi Maharani \& Mukaram. 2018. Pengaruh ROA dan NPM Terhadap Pertumbuhan Laba Pada Perusahaan Sektor Industri Barang Konsumsi Yang Terdaftar di Bursa Efek Indonesia. Jurnal Riset Bisnis dan Investasi. Vol.4 No. 12018 ISSN : 2460-8211.

Sinambela, Lijan Poltak. Metode Penelitian Kuantitatif: Untuk Bidang Administrasi, Kebijakan Publik, Ekonomi, Sosiologi, Komunikasi dan Ilmu Sosial Lainnya. Graha Ilmu: Yogyakarta.

Subramanyam, K.R \& Wild, Jhon J. 2014. Analisis Laporan Keuangan. Buku 1. Salemba Empat: Jakarta. 